\title{
The Black Sea from a "Safe" Distance: Guest Editor's Introduction
}

\author{
Volodymyr Kravchenko \\ University of Alberta
}

\section{Translated from Ukrainian by Ksenia Maryniak}

W hy was an academic conference devoted to problems in the Black Sea basin held in landlocked Kharkiv? Those who wish to find the answer to this question would do well to recall that in 2010, Kharkiv was the place where the "Agreement between Ukraine and Russia on the Black Sea Fleet in Ukraine" (widely referred to as the Kharkiv Pact or Kharkiv Accords) was signed. Upon travelling even farther into the depths of history, one would see how important the strategic role of Kharkiv was in Russia's expansion and modernization of the southern reaches of its empire. As well, Kharkiv seemed to attract more than its fair share of people from the Balkan region, particularly those from what is now Serbia and Bulgaria. In this respect it suffices to mention the founder of Kharkiv University, Vasyl' Karazyn (Russ. Vasilii Karazin, 1773-1842), and two of its professors, Teodor Filipović (1778-1807; pseud. Božidar Grujović), who authored the first constitution and laws of Serbia, and Marin Drinov (1838-1906), who was among the founders of the constitution and national academy of sciences of Bulgaria. Against this background, the North-South axis of Ukraine and Kharkiv's symbolic geography appears no less important than the East-West axis.

The above-mentioned explains to a certain extent why the Canadian Institute of Ukrainian Studies (CIUS), which itself is located in the landlocked provincial capital of Alberta-Edmonton-came to be included as an organizer and sponsor of the conference. To be sure, there were no analogous "fateful" treaties with the US, for example, concerning the lease of a base for its fleet in Hudson Bay; however, numerous immigrants in Alberta do have roots in the Balkan countries, not to mention Ukraine.

In 2013, the CIUS planned to hold an international summer school in Sevastopol, whose co-organizers were to include the Wirth Institute for Austrian and Central European Studies at the University of Alberta and Kharkiv National University. However, no one could have predicted that the Kharkiv Accords would be a prologue to the annexation of Crimea by the Russian Federation in 2014. As a result, the CIUS's summer school project 
had to be postponed. Nevertheless, the political and scholarly significance of the southern vector of Ukrainian politics, long underestimated and outside the limelight of Ukraine's quest for its proper place in global geopolitics, is unquestionably on the rise today.

During the 2018 conference in Kharkiv, an event took place that graphically demonstrated the dangerous consequences of Russia's annexation of Crimea not only for the Black Sea region but for the entire world. On 25 November Russian coast guards seized three Ukrainian ships in international waters and held them, along with their crews, for nearly a year in captivity. As I am writing this piece, it has just been reported that a Russian military jet carried out "mock attacks" on the Dutch frigate HNLMS Evertsen (Sterling). The day before, the British warship HMS Defender was also targeted by what is claimed to be either a real, preventive, or a propaganda attack from the Russian side (Bateman). Both of these ships were navigating between Ukraine and Georgia in international waters.

The implications of Russia's aggressive policy for its neighbours are obvious: the Black Sea is becoming more militarized and therefore more dangerous. For Ukraine, this is an existential matter, for in the vivid imagery of Ivan Lysiak-Rudnyts'kyi, "Crimea in foreign hands is like the barrel of a pistol held to Ukraine's temple" (81). With all probability, Georgian intellectuals or politicians would say something similar concerning South Ossetia, which has remained under the Russian control since 2008. The Black Sea is a part of the Ukrainian-Russian borderland that has been a contested ground between the two post-Soviet states. First of all, this means that security issues in this region are coming to the fore, and second, they have clearly acquired an international dimension.

In assessing this dimension, historians are naturally drawn to seeking analogues for the present situation in the past, and therefore their attention is focused on geopolitical problems with a characteristic rhetoric: "between East and West," Antemurale, Intermarium (Ukr.: Mizhmor"ia; Pol.: Międzymorze), cordon sanitaire etc. Meanwhile, history is often interpreted from not only a geopolitical but also a geocultural or civilizational perspective, and the realpolitik often acquires a symbolic dimension regardless of the wishes of the actors.

For Ukraine, which is still finding its legs with regard to national consolidation, history is not just a matter of the past. Ukraine is only partially integrated into neighbouring political and international economic structures, and its influence in each of them is inversely proportional to its dependence on them. In the Black Sea region, Ukraine's position is particularly uncertain, especially given that the region itself is rather problematic.

Do the nations around the Black Sea have anything in common other than geography? As always, history provides evidence both pro and contra. 
On the one hand, there are thousand-year-old mutual cultural and political interactions, lively trade, recreation, and tourism, as well as a unique culinary tradition. On the other hand, there have been numerous conflicts, "Balkanization," re-identification, and reconfiguration of this geopolitical space. The rhetoric of "dialogue" and "friendship" is no longer able to outweigh the historical legacy of imperial, religious, and national antagonisms in this part of the world. Thus, the Black Sea region might be considered a historical entity, but it did not quite become a region in the contemporary political sense from the point of view of security and common interests of the people and countries inhabiting this territory.

Stuck between the two heirs to the Byzantine Empire, Russia and Turkey, with their deeply rooted psychological-historical complexes and geopolitical ambitions, the small nation-states of the Black Sea basin are not yet able to disengage themselves from the gravity of history and generate momentum as a geography of regional co-operation. If there is any doubt, suffice it to analyze how differently the Black Sea countries reacted to Russia's aggressive policies in Georgia and in Ukraine. Is it possible to assume, then, that the new programs of co-operation between the Black Sea countries and their neighbours are motivated by purely economic and not geopolitical considerations?

The international conference "The Black Sea and Black Sea Region As a Contact Zone of Civilizations and Cultures" that was held in 2018 at Kharkiv National University-hosted under the 9th Annual Drinov Sessions by its Bulgarian and Balkan Studies Centre-aimed to promote dialogue between the various peoples and countries in the region. At this conference, the CIUS initiated and organized a round table titled "Problems of Regional Security and Integration in the Context of Globalization: From the Intermarium Concept of the Twentieth Century to the 'Three Seas' Project of the TwentyFirst Century." Not all of the many participants were able to submit their texts for publishing. Nevertheless, some of the presentations given at this meeting form the basis of the articles published herein. I am certain that despite the long delay, they remain timely and relevant. 


\section{Works Cited}

Bateman, Tom. "HMS Defender: AIS Spoofing Is Opening up a New Front in the War on Reality." $\quad 28$ Juronews, June 2021, https://www.euronews.com/next/2021/06/28/hms-defender-ais-spoofingis-opening-up-a-new-front-in-the-war-on-reality. Accessed 27 July 2021.

Lysiak-Rudnyts'kyi, Ivan. "Novyi Pereiaslav," Suchasnist' vol. 49, no. 20, September 1962, pp. 75-96.

Sterling, Toby. “Dutch Defence Minister: 'Irresponsible' Russian Jets Harassed Frigate in Black Sea."” Reuters, 29 June 2021, https://www.reuters.com/world/europe/dutch-defence-ministry-saysrussian-jets-harassed-frigate-black-sea-2021-06-29/. Accessed 27 July 2021.

"The Black Sea and Black Sea Region As a Contact Zone of Civilizations and Cultures." Conference, Kharkiv National University, 22-23 November 2018, https://www.univer.kharkov.ua/en/research/all_conferences/conferences?ne ws id=5203. Accessed 20 July 2021. 